ORNL/M--6/59

C/ORNL/94-0252F

OAK RIDGE

NATIONAL

LABORATORY

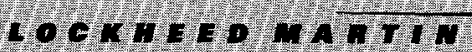
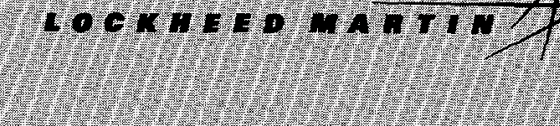

1.

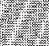

15.

3.
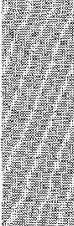

.

\section{Removal of Heteroatoms and Metals from Crude Oils by Bioconversion Processes}

E. N. Kaufman

DATRBOTHON OF THS DOCUMENT is UMAMTEO MMSTER 
This report has been reproduced directly from the best available copy.

Available to DOE and DOE contractors from the Office of Scientific and Technical Information, P.O.Box 62, Oak Ridge, TN 37831; prices available from (423) 576-8401, FTS 626-8401.

Available to the public from the National Technical Information Service, U.S. Department of Commerce, 5285 Port Royal Rd., Springfield, VA 22161

This report was prepared a an account of work sponsored by an agency of the United States Government. Neither the United States Governinent nor any agency thereof, nor any of their employees, makes any warranty, express or implied, or assumes any legal liability or responsibility for the accuracy, completeness, or usefulness of any information, apparatus, product, or process disclosed, or represents that its use would not infringe privately owned rights. Reference herein to any specific commercial product, process, or service by trade name, trademark, manufacturer, or otherwise, does not necessarily constitute or imply its endorsement, recommendation, or favoring by the United States Government or any agency thereof. The view and opinions of authors expressed herein do not necessarily state or reflect those of the UnitedStatesGovemment or any agjency thereot. 


\section{DISCLAIMER}

This report was prepared as an account of work sponsored by an agency of the United States Government. Neither the United States Government nor any agency thereof, nor any of their employees, makes any warranty, express or implied, or assumes any legal liability or responsibility for the accuracy, completeness, or usefulness of any information, apparatus, product, or process disclosed, or represents that its use would not infringe privately owned rights. Reference herein to any specific commercial product, process, or service by trade name, tradematk, manufacturer, or otherwise does not necessarily constitute or imply its endorsement, recommendation, or favoring by the United States Government or any agency thereof. The views and opinions of authors expressed herein do not necessarily state or reflect those of the United States Government or any agency thereof. 


\section{DISCLAMMIXR}

Portions of this document may be illegible in electronic image products. Images are produced from the best available original docemenert. 
Chemical Technology Division

\author{
CRADA Partial Report \\ for \\ CRADA Number ORNL94-0252F
}

\title{
REMOVAL OF HETEROATOMS AND METALS FROM CRUDE OILS BY BIOCONVERSION PROCESSES
}

\author{
E. N. Kaufman \\ Date Published ---- October 1997 \\ Prepared by the \\ Oak Ridge National Laboratory \\ Oak Ridge, Tennessee 37831-6226 \\ managed by \\ Lockheed Martin Energy Research Corp. \\ for the \\ U.S. Department of Energy \\ under contract DE-AC05-96OR22464
}

Approved for public release;

further dissemination unlimited 


\title{
Removal of Heteroatoms and Metals from Crude Oils by Bioconversion Processes
}

\author{
A Partial CRADA Report ${ }^{*}$ for ORNL94-0252F \\ covering work between \\ Oak Ridge National Laboratory \\ and \\ Union Oil Company (UNOCAL)
}

Eric N. Kaufman ${ }^{* *}$, Ph.D.

\footnotetext{
"This work was supported by the Research supported by the Oil and Gas Processing Program of the Office of Fossil Energy, United States Department of Energy under contract DE-AC05-96OR22464 with Lockheed Martin Energy Research Corp.

** Corresponding author: (423) 574-6624, ekn@ornl.gov
} 


\section{Removal of Heteroatoms and Metals from Crude Oils by Bioconversion Processes}

A Partial CRADA Report for ORNL94-0252F

Covering work between

Oak Ridge National Laboratory

and

Union Oil Company

Eric N. Kaufman, Ph.D.

\section{Contents}

$\begin{array}{lr}\text { EXECUTIVE SUMMARY___ } & 3 \\ \text { INTRODUCTION } & 4 \\ \text { CRADA TASKS_ } & 4 \\ \text { RESULTS } & 5 \\ \text { PUBLICATIONS } & 11\end{array}$




\section{EXECUTIVE SUMMARY}

The objective of this Cooperative research and Development Agreement project between Oak Ridge National Laboratory (ORNL) and Baker Performance Chemicals (BPC), Chevron, Energy BioSystems, Exxon, UNOCAL and Texaco is to investigate the biological desulfurization of crude oil. Biological removal of organic sulfur from crude oil offers an attractive alternative to conventional thermochemical treatment due to the mild operating conditions afforded by the biocatalyst. In order for biodesulfurization to realize commercial success, reactors must be designed which allow for sufficient liquid / liquid and gas / liquid mass transfer while simultaneously reducing operating costs. To this end we have been developing advanced bioreactors for biodesulfurization and have been studying their performance using both actual crude oil as well as more easily characterized model systems.

This CRADA was originally established to be a 3 year program, but was extended to 5 years due to continuing interest. Because of business restructuring, UNOCAL, whose activities focused upon the supply and analysis of crude oil samples, was unable to continue its participation in the CRADA. Hence this report is designed to cover only UNOCAL's contribution to the CRADA as other aspects of the research are not yet complete.

Experiments investigating the biological oxidative desulfurization of crude oil demonstrated that while dibenzothiophene like structures were readily degraded $(>90 \%$ in $48 \mathrm{~h}$ ) this desulfurization had minimal impact upon the total sulfur in the crude oil. This is because these structures represent less than $1 \%$ of the total sulfur found in the crude. Additional research is needed investigating sulfur speciation in crude oil with increased efforts upon broadening the sulfur specificity of the biocatalyst. 


\section{INTRODUCTION}

Biological removal of organic sulfur from crude oil offers an attractive alternative to conventional thermochemical treatment due to the mild operating conditions afforded by the biocatalyst. In order for biodesulfurization to realize commercial success, reactors must be designed which allow for sufficient liquid / liquid and gas / liquid mass transfer while simultaneously reducing operating costs. To this end, we have investigated the use of electro-spray reactors for the desulfurization of the model compound dibenzothiophene (DBT) as well as actual crude oil. The electro-spray reactor (ESR) creates an emulsion of aqueous biocatalyst ( $5-20 \mu \mathrm{m}$ diameter droplets) in the organic phase by concentrating forces at the liquid /liquid interface rather than imparting energy to the bulk solution as is done in impeller mixed reactors. Experiments are being conducted in the ESR to determine the rates of DBT oxidation and are being compared to results obtained in a batch stirred reactor (BSR).

\section{CRADA TASKS}

UNOCAL's task was to evaluate the extent of desulfurization of crude oil, when the crude was treated with the bacteria IGTS8. This bacteria desulfurizes dibenzothiophene type structures in the oil as shown in Figure 1. The advantage o this biocatalyst relative to others is that it desulfurizes while leaving the hydrocarbon intact rather than mineralizing the compound to carbon dioxide. This allows for retention of fuel value. Experiments were performed using both "Sand Flat" oil supplied by Texaco as well as "Van Texas" oil supplied by UNOCAL. Characteristics of these two oils are shown in Table 1.

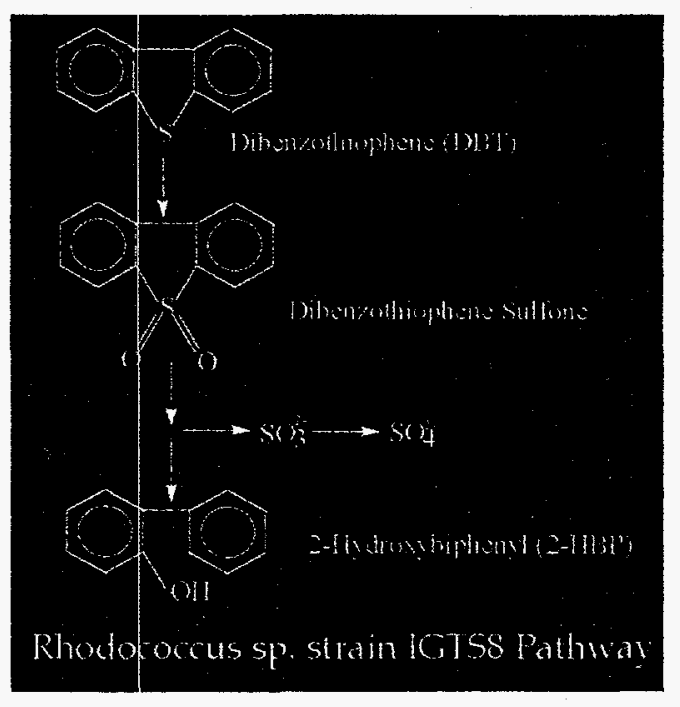

Figure 1. Pathway of desulfurization of dibenzothiophene by IGTS8. 
Table 1. Characteristics of Oils Investigated

\begin{tabular}{|c|c|c|}
\hline OIL & API Gravity & Total Sulfur \\
\hline Midway Sunset & $12-13^{\circ}$ & $1.40 \%$ \\
\hline Van Texas & $22-24^{\circ}$ & $0.96 \%$ \\
\hline Sand Flat & $22-24^{\circ}$ & $2.00 \%$ \\
\hline
\end{tabular}

\section{RESULTS}

All experiments were performed using Rhodococcus IGT-S8 as the biocatalyst. Experiments in batch stirred reactors (BSR) were performed on Van Texas and Sand Flat crude oils. Total sulfur analysis was conducted by Texaco. The total sulfur content did not decrease in any of the experiments. Analysis of individual sulfur species for the same run ( $r 36$ ) by UNOCAL (Figure 2) has shown $60-90 \%$ reduction in DBT and C1, C2 substituted DBT's for Sand Flat oil after 48 hours of treatment and greater than $90 \%$ reduction of these species from Van Texas crude in the same time period. Nine individual DBT derivatives were identified and quantified by UNOCAL and the total sulfur content of these compounds in Sand Flat oil before treatment amounted to about $0.013 \%$. This is a very small fraction of the total sulfur content of the oil and it is not surprising that the total sulfur analysis conducted by Texaco did not show a decrease after treatment even with $60-90 \%$ reduction of the individual sulfur compounds measured.

BSR runs performed with Van Texas and Sand Flat crude oil were repeated to provide Texaco with more oil sample to perform individual sulfur species analysis as conducted by UNOCAL. Treated oil was fractionated into aromatic, aliphatic, alkane, and asphaltene fractions and the sulfur species in the aromatic fraction was analyzed using a sulfur chemiluminescent detector on a gas chromatograph. As shown in Figure 3, while lower molecular weight species such as dibenzothiophene were desulfurized, no desulfurization took place among higher molecular weight compounds. Biological treatment reduced the total sulfur content of the aromatic fraction from 3.8 to $3.2 \%$ while not appreciably altering the total sulfur content of the whole oil.

These results point toward the need for a more thorough understanding of the sulfur species present in the crude oil as well as further biocatalyst development work to broaden the sulfur specificity of microorganism. 


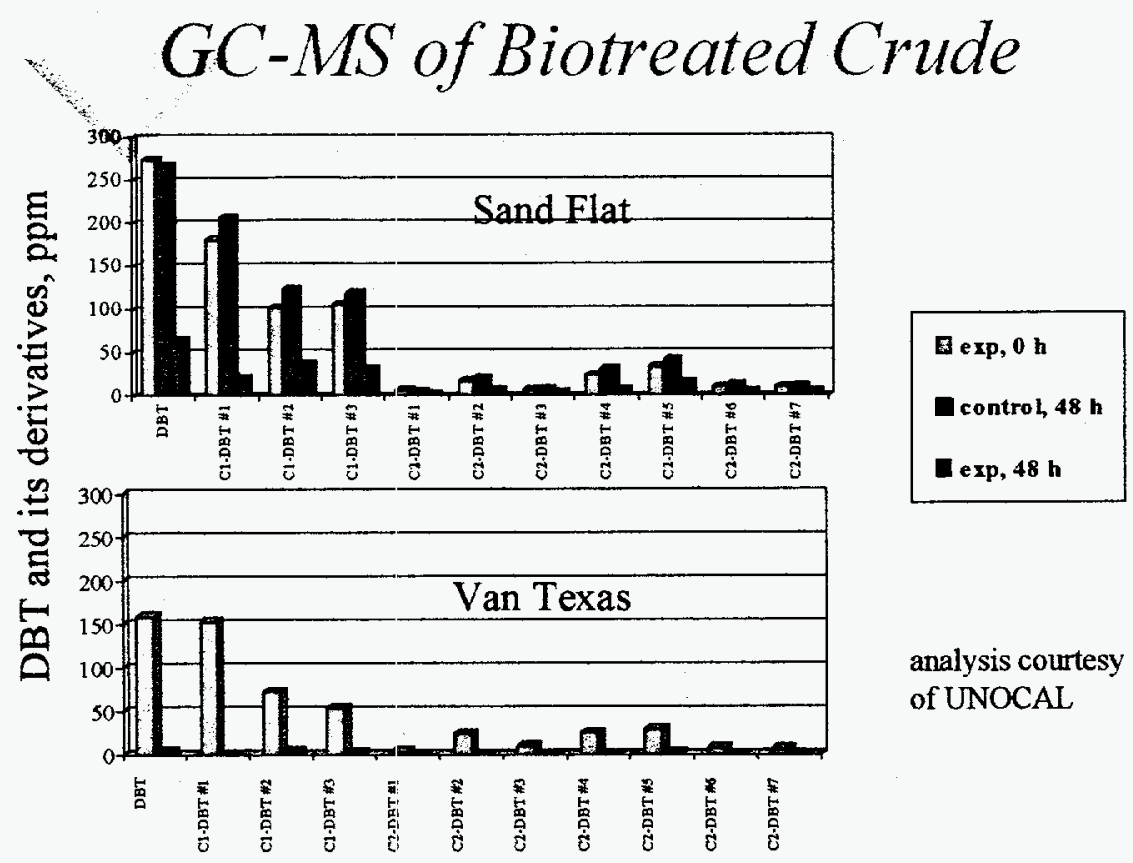

Figure 2: Biodesulfurization of DBT and substituted DBT's in crude oil.

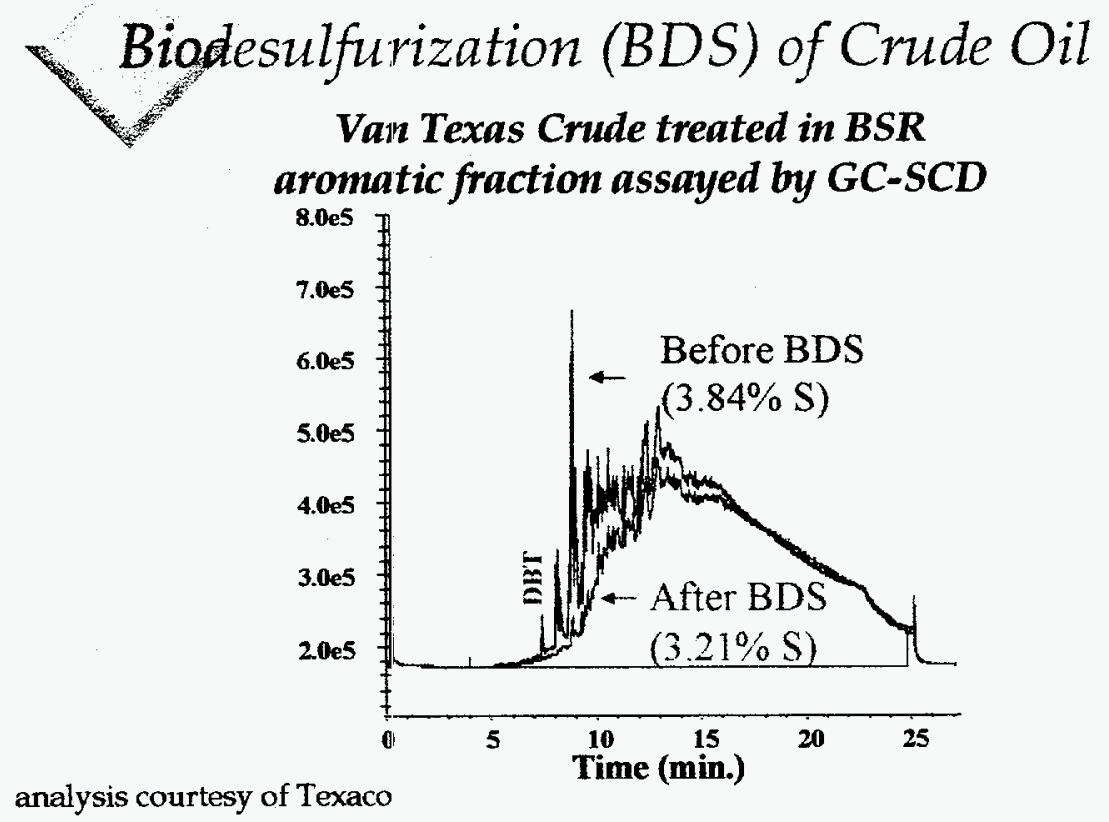

Figure 3. Sulfur speciation in the aromatic fraction as analyzed by gas chromatography with a sulfur chemiluminescent detector. 
The following letter is a report from UNOCAL which serves to further outline their involvement in this CRADA: 


\title{
UNOCAL무
}

June 27, 1997

\author{
Dr. Eric Kaufman \\ Lockheed Martin Energy Systerns \\ P.O. Box 2008, MS 6226 \\ Oak Ridge, TN 37831-6226
}

Dear Dr. Kaufman,

This report was written at your request to document Unocal's participation in the Biodesulfurization CRADA (FWP FEAC300) at the Oak Ridge National Laboratory. Unocal's contribution to the effort was in the form of consulting, analytical support and equipment and material supply. The breakdown of the support over the 28-month period is as follows:

\begin{tabular}{|l|l|}
\hline & \\
\hline $\begin{array}{l}\text { Consulting/Travel/Technical Awareness of } \\
\text { Developments in the Field of Biodesulfurization }\end{array}$ & $\$ 50,500$ \\
\hline Laboratory Analysis & $\$ 12,000$ \\
\hline Equipment and material supply & $\$ 6,400$ \\
\hline Total & $\$ 66,900$ \\
\hline
\end{tabular}

The consulting/travel/technical awareness includes 6 days of CRADA meetings, reviewing work and data, maintaining an awareness of developments in petroleum biodesulfurization and associated travel costs. The laboratory analysis includes characterization of two candidate oil samples and high resolution gas chromatography/mass spectrometry of biotreated and control samples. A gas chromatograph detector was purchased for use at the Oak Ridge National Laboratory and the installation costs were paid by Unocal. Samples of oil were procured from the Midway-Sunset and Van Field and shipped at Unocal's expense.

The remainder of this report documents the analytical procedures employed to analyze the oil samples.

\section{Water content}

The water content of oil samples was reduced to less than $0.5 \%$ unless the presence of water was specifically desired. The water concentration was measured with an automated commercial Karl-Fischer titrator. Water was removed by diluting the oil with dichloromethane or toluene to reduce viscosity and drying over calcium sulfate.

\section{Elemental Analysis for Carbon, Hydrogen, Sulfur and Nitrogen}

This method determines the carbon, hydrogen, nitrogen, and sulfur content of solid and liquid samples using an elemental analyzer. The detection limits are routinely $0.1 \mathrm{wt} \%$ for carbon, hydrogen, nitrogen, 
and sulfur, respectively. The relative precision (\%RSD) of this method using the solid autosampler for the determination of CHNS is $0.4 \%, 1.2 \%, 3.3 \%$, and $2.3 \%$, for carbon, hydrogen, nitrogen and sulfur, respectively. When the liquid autosampler is used, the \%RSD for carbon and hydrogen is $0.34 \%$ and $0.75 \%$, respectively.

This method is based on the use of a conventional carbon/hydrogen/nitrogen/sulfur (CHNS) elemental analyzer (Carlo Erba EA1 108). For the determination of total wt\% CHNS, a weighed sample is placed into an oxygen-rich atmosphere within a combustion tube at a temperature of $1020^{\circ} \mathrm{C}$. The sample is combusted under conditions where approximately 85 to $90 \%$ of the oxidation takes place as flash combustion. Further oxidation is promoted catalytically by tungstic oxide in the upper portion of the combustion tube. The excess oxygen is removed from the system by oxidation of a copper bed in the lower portion of the combustion tube. The resulting combustion gases, carbon dioxide, nitrogen, water, and sulfur dioxide, are swept into a chromatographic column (Porapak QS 50-80 mesh) using a helium carrier gas. A thermal conductivity detector is used for quantifying each component. A single sample analysis requires approximately 13 minutes.

The method requires standardizing the instrument with a standard of known composition, such as sulfanilamide when using the solid autosampler or toluene when the liquid autosampler is used. The best standard is one that has a similar composition to the sample to be determined. After standardization, samples are weighed into tin capsules, which are subsequently crushed to remove all trapped air before analysis. Viscous samples require using a tin capsule within a tin capsule to prevent leakage. Volatile or liquid samples are weighed into a thick-wall tin capsule which can be purged with helium and hermetically sealed. If the samples are extremely volatile and do not maintain a constant weight on the balance, the liquid autosampler must be employed.

\section{Nickel and Vanadium}

This test method covers the determination of nickel and vanadium in liquid petroleum hydrocarbons and in solid petroleum hydrocarbons that can either be liquefied with moderate heating or dissolved in a suitable organic solvent. The applicable concentration range will vary to some extent with the instrumentation used and the nature of the sample. Optimum conditions will allow the direct determination of nickel and vanadium in essentially paraffinic samples at concentrations exceeding 0.5 ppm.

The oil sample (after heating or diluting if necessary) is poured into a polyethylene cup which is then covered with an ultra-thin Mylar film window. The sample is irradiated in an X-ray spectrometer with a rhodium or tungsten target tube. The resultant fluorescent $x$-rays from the sample pass through the Mylar window and a slit to the analyzing crystal, from which the $\mathrm{Ni} \mathrm{K} \alpha$ and $\mathrm{V} \mathrm{K} \alpha \mathrm{x}$-ray lines are reflected into a proportional counter. The counts from each line are summed for a period of time, as are the counts from the $S \mathrm{~K} \alpha \mathrm{x}$-ray line, in order to correct the nickel and vanadium concentrations for the presence of sulfur. The results are computed from calibration curves that are updated prior to sample analysis. 


\section{Viscosity}

Viscosity is measured with a Brookfield viscometer ASTM 2983.

Simulated Distillation (Capillary Gas chromatography)

\section{Column}

A 5.0 meter $x 0.32 \mathrm{~mm}$ id Ultra 1 crosslinked methyl silicone gum with a film thickness of $0.52 u \mathrm{~m}$. This is available from Hewlett Packard: part number 19091A-115.

\section{GC Conditions}

Set up the gas chromatograph with helium as the carrier gas. Set the dead time at $25^{\circ} \mathrm{C}$ for 4 seconds by adjusting the head pressure (the head pressure reading is about $6 \mathrm{PSI}$ ). Set the injector temperature to $320^{\circ} \mathrm{C}$ and the detector temperature to $350^{\circ} \mathrm{C}$. The oven temperature is programmed as follows: $-20^{\circ} \mathrm{C}$ for 2 minutes, increasing at a rate of $10^{\circ} \mathrm{C} / \mathrm{min}$. to $350^{\circ} \mathrm{C}$, then hold for 22 minutes for each run.

\section{Gas Chromatography/Mass Spectrometry}

I requested a brief methods description from the outside laboratory. I will forward the information when I receive it. If you choose to publish this data, I would like to acknowledge the outside lab and chemist who performed the work, APTI Geosciences, Houston, Texas and Dr. Zbigniew Wilk

I personally enjoyed the interaction within the CRADA. Unfortunately, Unocal has changed considerably from the time of our initial involvement in the CRADA and hydrocarbon desulfurization technology has not received support from our operating groups. I wish the CRADA and you good luck in your endeavors.

Regards,

Clifford D. Juengst 


\section{PUBLICATIONS}

E.N. Kaufman, J.B. Harkins, M. Rodriguez, S.E. Murphy, P.T. Selvaraj and C. Tsouris, "Development of an Electro-Spray Bioreactor for Crude Oil Processing." 1997, Fuel Processing Technology. in press.

H.M. Lizama and E.N. Kaufman, "Biotreatment of $\mathrm{H}_{2} \mathrm{~S}$ in the Petroleum Industry," in D.S. Holmes and R.W. Smith (eds.), Minerals Bioprocessing II, The Minerals, Metals and Materials Society, Warrendale, PA, 1995, 241-253.

Tsouris, C., H. M. Lizama, M. A. Spurrier, T. L. Takeuchi, and T. C. Scott, "Hydrodynamics of Bioreactors Systems for Liquid-Liquid Contacting," Appl. Biochem. And Biotech. (1996) vol. 57, 581-592.

Tsouris, C., S.H. Neal, V. M. Shah, M. A. Spurrier, and M. K. Lee Comparison of Liquid-Liquid Dispersions Formed by a Stirred Tank and Electrostatic Spraying," Chem. Eng. Commun. (1997).160: 175-197.

H.M. Lizama, L.A. Wilkins, and T.C. Scott, "Dibenzothiophene Sulfur Can Serve as the Sole Electron Acceptor During Growth by Sulfate-Reducing Bacteria," (1995) Biotechnology Letters, 17: 113-116 


\section{INTERNAL DISTRIBUTION}

1-4. E. N. Kaufman

5-6. B. H. Davison

7. R. T. Jubin

8. R. R. Judkins

9. Laboratory Records, RC

10. A. J. Luffman

11. L. E. McNeese

12. C. A. Valentine

\section{EXTERNAL DISTRIBUTION}

13. A. B. Crawley, Department of Energy, Bartlesville Project Office, Post Office Box 1398, Bartlesville, Oklahoma 74005

14. Department of Energy - Work for Others Office, MS-G209

15. P. L. Gorman, ORNL Site Office, DOE-ORO, Post Office Box 2008, Oak Ridge, TN. 37831-6269

16. A. M. Hartstein, Office of Oil and Gas Processing, U.S. Department of Energy, FE-32, 4067/270, Washington, D.C. 20585

17. C. Juengst, UNOCAL Corporation, 14141 Southwest Freeway, Room 3026, Sugar Land City, Texas 77478

18-19. Office of Scientific and Technical Information, Post Office Box 62, Oak Ridge, Tennessee 37831. 